\title{
16. Különleges jogrendi szabályok Lengyelországban
}

NÉMETH ZOLTÁN

\section{A különleges jogrend alkotmányos és törvényi szintủ szabályozása, valamint a különleges jogrend esetkörei}

A lengyel alkotmány ${ }^{1}$ XI. fejezete rendelkezik a kivételes hatalomgyakorlás során alkalmazható rendkívüli intézkedések köréről. Azon rendkívüli helyzetekben, amikor a normál időszaki alkotmányos intézkedések nem elégségesek, az alábbi rendkívüli helyzetek vezethetők be: hadiállapot (stan wojenny), szükségállapot (stan wyjątkowy), illetve veszélyhelyzet (stan klęski żywiotowej). ${ }^{2}$

A hadiállapotot a Minisztertanács ${ }^{3}$ kérelmére az állam külső fenyegetettsége, a Lengyel Köztársaság területe ellen elkövetett fegyveres agresszió esetén, valamint akkor, ha a nemzetközi egyezmény agresszióval szembeni közös védelmi kötelezettséget ír elő, a köztársasági elnök az állam egész területére vagy annak valamelyik részére hirdeti ki. ${ }^{4}$ Mindezt

1 A Lengyel Köztársaság alkotmánya (Konstytucja Rzeczypospolitej Polskiej z dnia 2 kwietnia 1997 r.) (a továbbiakban: alkotmány).

2 Lakatos, 2014, 8. o.

3 Lengyelországban a kormány hivatalos elnevezése Minisztertanács.

4 Alkotmány 229. cikk.

Dr. Németh Zoltán, LLM

zoltan.nemeth@mfi.gov.hu

kutató (Mádl Ferenc Összehasonlító Jogi Intézet)

Németh, Z. (2021) 'Különleges jogrendi szabályok Lengyelországban’ in Nagy, Z., Horváth, A. (szerk.) A különleges jogrend és nemzeti szabályozási modelljei, 358-375. o. Budapest: Mádl Ferenc Összehasonlító Jogi Intézet.

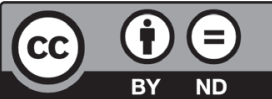


a hadiállapotról szóló törvény ${ }^{5}$ akként egészíti ki, hogy Lengyelország függetlensége, területi integritása, jelentős gazdasági érdekeltségei elleni támadás, illetve külső fenyegetettség esetén olyan helyzetben lehet elrendelni, amely akadályozza, illetve gátolja az államapparátus rendes múködését. ${ }^{6} \mathrm{~A}$ Minisztertanács megállapítja a hadiállapot elrendelésének okait, és javaslatot tesz a jogok korlátozására a fenyegetés komolyságához mérten. A hadiállapot bevezetésétől számított 48 órán belül a köztársasági elnök kezdeményezi rendeletének képviselőházi ellenjegyzését. A képviselőház (Sejm) a kezdeményezést haladéktalanul megtárgyalja, és a képviselók legalább felének jelenlétében abszolút többséggel hatályon kívül helyezheti azt.7 Amennyiben a képviselőház nem helyezi hatályon kívül a köztársasági elnök rendeletét, azt nemcsak a szokásos módon (a hivatalos közlönyben), hanem a helyi önkormányzatokon keresztül, valamint a tömegmédiában is közzé kell tenni. ${ }^{8}$ A külügyminiszter pedig köteles a hadiállapot bevezetésének tényét és okát az ENSZ és az Európa Tanács főtitkárának bejelenteni. ${ }^{9}$

A hadiállapotot az elnök a Minisztertanács kérelmére kiadott rendeletével szünteti meg akkor, ha a fenyegetettség megszúnt, és az állam rendes múködése helyreállt. ${ }^{10}$

A hadiállapotot az alkotmánybíróság is megszüntetheti, ugyanis a rendelet, amellyel a hadiállapotot a köztársasági elnök elrendeli, központi állami szerv által kiadott jogi aktusnak minősül, amelynek alkotmánnyal, ratifikált nemzetközi egyezményekkel és törvényekkel való összhangja tekintetében az alkotmánybíróság határoz. Ha az alkotmánybíróság ütközést talál, a rendelet érvénytelenné válik. ${ }^{11}$

A szükségállapot elrendelésének szabályait az alkotmány mellett egy külön szükségállapoti törvény ${ }^{12}$ is szabályozza. Az állam alkotmányos rendjének, az állampolgárok vagy a közrend fenyegetettsége esetén a Minisztertanács kérelmére a köztársasági elnök kilencven napnál nem hosszabb, meghatározott időre az állam egész területére vagy annak valamelyik részére kihirdeti a szükségállapotot. ${ }^{13}$ Mindezeken túl a Szükségállapoti tv. alapján szükségállapot rendelhető el terrorcselekmény kapcsán, valamint a kibertér biztonsága érdekében. ${ }^{14}$

5 A hadiállapotról, a fegyveres erők legfelsőbb parancsnokának hatásköréről és a Lengyel Köztársaság alkotmányos szerveinek való alárendelés szabályairól szóló 2002. augusztus 29-i 1301. törvény (Dz.U. 2002 nr 156 poz. 1301 Ustawa z dnia 29 sierpnia 2002 r. o stanie wojennym oraz o kompetencjach Naczelnego Dowódcy Sił Zbrojnych i zasadach jego podległości konstytucyjnym organom Rzeczypospolitej Polskiej) (a továbbiakban: Hadiállapot tv.).

6 Hadiállapot tv. 2. cikk 1a. bekezdés.

7 Alkotmány 231. cikk.

8 Hadiállapot tv. 4-5. cikk.

9 Hadiállapot tv. 6. cikk.

10 Hadiállapot tv. 8. cikk.

11 Alkotmány 188. cikk.

12 A szükségállapotról szóló (2002. július 21-i) törvény (Ustawa z dnia 21 czerwca 2002 r. o stanie wyjątkowym) (a továbbiakban: Szükségállapoti tv.).

13 Alkotmány 230. cikk 1. bekezdés.

14 Szükségállapoti tv. 2. cikk (1) bekezdés. 
A köztársasági elnök szükségállapotot kihirdető rendeletének képviselőházi ellenjegyzése, valamint közzététele a hadiállapotnál leírtak szerint zajlik.15

Az állam alkotmányos rendje elleni támadás definícióját, amely a szükségállapot elrendelésének feltételeként került rögzítésre, sem az alkotmány, sem más törvény nem tartalmazza. Ugyanígy az állampolgárok fenyegetettségének sincs egységes definíciója, ez a meghatározás az állampolgároknak nem csupán a fizikai, hanem a gazdasági biztonságára is vonatkozik.

Fôszabály szerint a szükségállapot megszúnik az elrendelt határidő lejártával, azonban ha annak közeledtével a szükségállapot elrendelésének okai még nem szűntek meg, illetve az állam rendes múködését nem állították helyre, a köztársasági elnök a képviselőház jóváhagyásával a szükségállapotot egyszer, hatvan napnál nem hosszabb időre rendeletével meghosszabbíthatja. ${ }^{16} \mathrm{~A}$ köztársasági elnök a szükségállapotot - a határidő lejárta előtt - a Minisztertanács kérelmére rendeletével meg is szüntetheti, ha az elrendelés okai megszúntek, és az állam rendes múködése helyreállt. ${ }^{17}$ Ugyancsak megszüntethető a szükségállapot - a hadiállapot vonatkozásában leírtak szerint - az alkotmánybíróság döntésével.

A különleges jogrend fent ismertetett két esetkörével ellentétben a veszélyhelyzetet nem a köztársasági elnök, hanem a Minisztertanács hirdeti ki természeti katasztrófa vagy ahhoz hasonló jellegú múszaki baleset következményeinek megelôzése vagy elhárítása céljából harminc napnál nem hosszabb, meghatározott időre az állam egész területére vagy annak valamelyik részére. A veszélyhelyzet meghosszabbításához vagy kiterjesztéséhez szükséges a képviselőház jóváhagyása is. ${ }^{18} \mathrm{~A}$ veszélyhelyzetről szóló törvény ${ }^{19}$ alapján azon természeti katasztrófák és múszaki hibák esetén rendelhető el veszélyhelyzet, amelyek nagyszámú ember életét vagy egészségét, jelentős mértékû́ vagyont, illetve a környezetet nagy területen veszélyeztetik, és mindezek védelme csak rendkívüli intézkedésekkel lehetséges. Emellett rögzíti, hogy veszélyhelyzet rendelhető el terrorcselekmény és kibertámadás esetén is. A törvény az értelmező rendelkezései között rögzíti mind a természeti katasztrófa, mind pedig a müszaki hiba fogalmát. ${ }^{20}$ Előbbi körébe a természeti erők múködésével kapcsolatos események tartoznak, mint például az erős szél, heves csapadék, szélsőséges hőmérséklet hosszan tartó előfordulása, földcsuszamlások, tüzek, aszály, árvizek, folyók, a tenger, tavak és víztartályok jegesedése, kártevők tömeges előfordulása, növényi vagy állatbetegségek, illetve az emberi fertőző betegségek. A műszaki hiba körébe pedig az épületek, műszaki eszközök vagy műszaki eszközrendszerek olyan hirtelen, váratlan károsodása vagy megsemmisülése tartozik, amely ezek használhatóságának megszúnését vagy tulajdonságainak elvesztését okozza. ${ }^{21} \mathrm{~A}$ Minisztertanács a veszély-

15 Alkotmány 231. cikk.

16 Alkotmány 230. cikk 2. bekezdés.

17 Szükségállapoti törvény 5. cikk (2) bekezdés.

18 Alkotmány 232. cikk.

19 A veszélyhelyzetról szóló 2002. április 18-i törvény (Ustawa z dnia 18 kwietnia 2002 r. o stanie klęski żywiołowej) (a továbbiakban: Veszélyhelyzeti tv.).

20 Veszélyhelyzeti tv. 3. cikk (1)-(2) bekezdés.

21 Veszélyhelyzeti tv. 3. cikk. 
helyzetet saját maga is kezdeményezheti, azonban hozhat ilyen tárgyú rendeletet az érintett vajdaság kérelmére is. A rendeletben köteles meghatározni a veszélyhelyzet okát, bevezetésének idôpontját, terjedelmét és időtartamát, valamint az emberi és polgári jogok szükséges korlátozásainak típusait. A rendeletet pedig mind az újságok, mind pedig a rádió- és televíziós műsorok músorszolgáltatói kötelesek haladéktalanul és ingyenesen nyilvánosságra hozni. ${ }^{22}$

A veszélyhelyzet a Minisztertanács képviselőházi hozzájárulás után kiadott rendeletével határozott idôtartamra meghosszabbítható. Főszabály szerint pedig akkor szúnik meg, ha az idő, amelyre elrendelték, eltelt. Annak lejárta előtt a Minisztertanács jogosult azt megszüntetni, amennyiben bevezetésének okai már nem állnak fenn. Emellett - a hadiállapotnál leírtak alapján - az alkotmánybíróság is megszüntetheti a veszélyhelyzetet a Minisztertanács azt elrendelő döntésével. ${ }^{23}$

\section{Az alapjogok korlátozásával kapcsolatos kérdések}

Az alkotmány második fejezete tartalmazza azokat az általános alapelveket, amelyek rendelkeznek többek között az alapjogok korlátozhatóságáról. Az alkotmány kimondja, hogy az ember veleszületett és elidegeníthetetlen méltósága az emberi és állampolgári szabadságok és jogok forrása. Ez a jog sérthetetlen, tiszteletben tartása és védelme a közhatalmi szervek kötelezettsége. ${ }^{24}$

Az alkotmány rögzíti, hogy az alkotmányos jogok és szabadságok gyakorlását csak törvény korlátozhatja, és csak olyan esetekben, amikor ez egy demokratikus államban a biztonság, a közrend, a természetes környezet, az egészség, a közerkölcs vagy mások szabadságai és jogai védelmében szükséges. Fontos kiemelni, hogy ezek a törvények nem sérthetik a szabadságok és jogok lényeges tartalmát. ${ }^{25}$

\begin{tabular}{|l|l|}
\hline \multicolumn{1}{|c|}{ Korlátozható alapjog } & \multicolumn{1}{c|}{ A korlátozó rendelkezés tartalma } \\
\hline $\begin{array}{l}\text { szabadsághoz való jog } \\
\text { (41. cikk) }\end{array}$ & $\begin{array}{l}\text { törvényben meghatározott okokból és törvényben meghatározott } \\
\text { eljárás alapján }\end{array}$ \\
\hline $\begin{array}{l}\text { tulajdonhoz való jog } \\
\text { (46. cikk) }\end{array}$ & $\begin{array}{l}\text { ellkobozni csak törvényben meghatározott esetekben és jogerős } \\
\text { bírósági határozat alapján lehet }\end{array}$ \\
\hline szülői jogok (48. cikk) & $\begin{array}{l}\text { csak törvényben meghatározott esetekben és jogerős bírósági } \\
\text { határozat alapján lehet }\end{array}$ \\
\hline
\end{tabular}

22 Veszélyhelyzeti tv. 5. cikk (3).

23 Veszélyhelyzeti tv. 6. cikk (1).

24 Alkotmány 30. cikk.

25 Alkotmány 31. cikk. 


\begin{tabular}{|c|c|}
\hline Korlátozható alapjog & A korlátozó rendelkezés tartalma \\
\hline $\begin{array}{l}\text { közlés szabadsága és titkossága } \\
\text { (49. cikk) }\end{array}$ & csak törvényben meghatározott esetekben és módon \\
\hline $\begin{array}{l}\text { magánlakás sérthetetlensége } \\
\text { (50. cikk) }\end{array}$ & csak törvényben meghatározott esetekben és módon \\
\hline $\begin{array}{l}\text { személyes adat szolgáltatása } \\
\text { (51. cikk) }\end{array}$ & csak törvényben meghatározott kivételekben \\
\hline $\begin{array}{l}\text { mozgásszabadság, lakóhely } \\
\text { és tartózkodási hely szabad } \\
\text { megválasztása } \\
\text { (52. cikk) }\end{array}$ & korlátait törvény határozza meg \\
\hline $\begin{array}{l}\text { lelkiismereti és vallássza- } \\
\text { badság ( } 53 . \text { cikk) }\end{array}$ & $\begin{array}{l}\text { nyilvános gyakorlása csak törvénnyel korlátozható, és csak olyan } \\
\text { esetekben, amikor ez az állambiztonság, a közrend, egészség, } \\
\text { erkölcs vagy mások jogai és szabadságai védelmének érdekében } \\
\text { szülkséges }\end{array}$ \\
\hline $\begin{array}{l}\text { véleménynyilvánítás sza- } \\
\text { badsága, sajtószabadság } \\
\text { (54. cikk) }\end{array}$ & előzetes cenzúra és a sajtó előzetes engedélyezése tilos \\
\hline gyülekezési jog (57. cikk) & csak törvény korlátozhatja \\
\hline $\begin{array}{l}\text { egyesülés szabadsága } \\
\text { ( } 58 . \text { cikk) }\end{array}$ & szabad, de kereteit törvény határozza meg \\
\hline $\begin{array}{l}\text { munkahely megválasztásának } \\
\text { szabadsága (65. cikk) }\end{array}$ & törvény állapíthat meg kivételeket \\
\hline $\begin{array}{l}\text { biztonságos és egészséges } \\
\text { munkakörülményekhez való } \\
\text { jog (66. cikk) }\end{array}$ & alkalmazásának módját törvény állapítja meg \\
\hline $\begin{array}{l}\text { szociális biztonsághoz való jog } \\
\text { (67. cikk) }\end{array}$ & terjedelmét és formáit törvény állapítja meg \\
\hline $\begin{array}{l}\text { egészséghez való jog } \\
\text { (68. cikk) }\end{array}$ & feltételeit törvény határozza meg \\
\hline $\begin{array}{l}\text { oktatáshoz való jog } \\
\text { (70. cikk) }\end{array}$ & $\begin{array}{l}\text { az oktatási kötelezettségek teljesítésének módját törvény hatá- } \\
\text { rozza meg }\end{array}$ \\
\hline
\end{tabular}

11. táblázat

Az egyes alapjogok korlátozása a lengyel alkotmányban

Forrás: a szerzô saját összeállitása 
A különleges jogrendi esetkörök tartalma kapcsán említésre érdemes az ezen időszakokban korlátozható jogok kérdése, amelyet az adott időszakra vonatkozó törvényekben kell rendezni. Az alkotmány meghatározza, hogy melyek azok az állampolgári szabadságok és jogok, amelyek a különleges jogrendi szituációkban sem korlátozhatók.

Így hadiállapot és szükségállapot idején sem korlátozható jogok: az emberi méltóság, állampolgárság, az élet védelme, az emberi bánásmód, a büntetőjogi felelősség kérdésköre, a bírósághoz fordulás joga, a személyhez fúződő jogok, a lelkiismereti és vallásszabadság, a petíció joga. Továbbá nem lehet az emberi és állampolgári szabadságokat és jogokat kizárólag fajra, nemre, nyelvre, vallásra vagy annak hiányára, társadalmi helyzetre, származásra vagy tulajdonra tekintettel korlátozni. ${ }^{26}$

A Hadiállapot tv., illetve a Szükségállapot tv. alapján korlátozható a gyülekezési jog, a sajtószabadság, a magántitokhoz való jog, a mozgás szabadsága és a tartózkodási hely szabad megválasztásának joga, illetve szükségállapotban időlegesen megfosztható szabadságától az a 18. életévét betöltött személy, akiről alaposan feltehető, hogy ennek hiányában az állam alkotmányos rendjét, az állampolgárokat vagy a közrendet fenyegeti. A veszélyhelyzet kapcsán az alkotmány úgy rendelkezik, hogy törvény korlátozhatja a gazdasági tevékenység szabadságát, a személyes szabadságot, a magánlakás sérthetetlenségét, a mozgásés letelepedési szabadságot, a sztrájkjogot, a tulajdonhoz való jogot, a munkához való jogot, a biztonságos és egészséges munkakörülményekhez való jogot, valamint a pihenéshez való jogot. ${ }^{27}$

\begin{tabular}{|c|c|c|c|}
\hline & Hadiállapot & Szükségállapot & Veszélyhelyzet \\
\hline $\begin{array}{c}\text { Nem } \\
\text { korlátozható }\end{array}$ & \multicolumn{3}{|c|}{$\begin{array}{l}\text { — az emberi méltóság } \\
\text { — állampolgárság } \\
\text { — az élet védelme } \\
\text { — az emberi bánásmód } \\
\text { — a büntetőjogi felelősség kérdésköre } \\
\text { — a bírósághoz fordulás joga } \\
\text { — a személyhez fúződő jogok } \\
\text { — a lelkiismereti és vallásszabadság, a petíció joga } \\
\text { — nem lehet az emberi és állampolgári szabadságokat és jogokat kizárólag fajra, } \\
\text { nemre, nyelvre, vallásra vagy annak hiányára, társadalmi helyzetre, szár- } \\
\text { mazásra vagy tulajdonra tekintettel korlátozni }\end{array}$} \\
\hline
\end{tabular}

26 Alkotmány 233. cikk 1. bekezdés.

27 Alkotmány 233. cikk 2. bekezdés. 


\begin{tabular}{|c|c|c|c|}
\hline & Hadiállapot & Szükségállapot & Veszélyhelyzet \\
\hline Korlátozható & \multicolumn{2}{|c|}{$\begin{array}{l}\text { — a gyülekezési jog } \\
\text { — a sajtószabadság } \\
\text { — a magántitokhoz való jog } \\
\text { — a mozgás szabadsága és a tartózkodási hely } \\
\text { szabad megválasztásának joga } \\
\text { — szükségállapotban időlegesen megfosztható } \\
\text { szabadságától az a 18. életévét betöltött személy, } \\
\text { akiről alaposan feltehető, hogy ennek hiányában } \\
\text { az állam alkotmányos rendjét, az állampol- } \\
\text { gárokat vagy a közrendet fenyegeti }\end{array}$} & $\begin{array}{l}\text { - a gazdasági tevékenység } \\
\text { szabadsága } \\
\text { — a személyes szabadság } \\
\text { — a magánlakás } \\
\text { sérthetetlensége } \\
\text { — a mozgás- és le- } \\
\text { telepedési szabadság } \\
\text { — a sztrájkjog } \\
\text { — a tulajdonhoz való jog } \\
\text { — a munkához való jog } \\
\text { — a biztonságos és } \\
\text { egészséges munka- } \\
\text { körülményekhez való jog }\end{array}$ \\
\hline
\end{tabular}

12. táblázat

A nem korlátozható és a korlátozható alapjogok Lengyelországban

Forrás: a szerző saját összeállítása

\section{Az egészségügyi válsághelyzet kezelése és a koronavírus-járvány}

A válságkezelésról szóló törvény ${ }^{28}$ alapján járványhelyzetben válságkezelési tervet kell készíteni, amelynek egyik sarkalatos pontja a szociális és orvosi ellátás megszervezése, ideértve a sürgősségi orvosi szolgáltatásokat is. Erről külön törvény, az állami sürgősségi orvosi szolgálatról szóló törvény ${ }^{29}$ rendelkezik.

Vajdasági szinten múködnek válságkezelő központok, amelyek gondoskodnak az egészségügyi ellátás megszervezéséről. Természeti katasztrófák esetén például a válságkezelő központ orvoskoordinátora gondoskodik arról, hogy az érintett intézményt a fennálló veszélyhelyzethez igazítva magasabb készültségi szintre állítsa.

Lengyelország egy részletesen szabályozott sürgősségi orvosi rendszert múködtet, amely egészségügyi vészhelyzetekben egy előre kialakított protokoll alapján végzi tevékenységét. ${ }^{30}$ A lengyel egészségügyi rendszer az alábbi jogszabályokon alapul:

- alkotmány;

28 2007. évi 89. számú törvény a válságkezelésről (Ustawa z dnia 26 kwietnia 2007 r. o zarządzaniu kryzysowym).

29 Ustawa z dnia 8 września 2006 r. o Państwowym Ratownictwie Medycznym.

30 A protokoll elérhetőa lengyel egészségügyi minisztérium honlapján:www.gov.pl/web/zdrowie/obowiazkoweubezpieczenie-zdrowotne (Letöltve: 2020. december 15.). 
— a betegek jogairól és a betegek ombudsmanjáról szóló törvény;31

- a közpénzekből finanszírozott egészségügyi szolgáltatásokról szóló törvény;32

— az orvosi tevékenységekről szóló törvény; ${ }^{33}$

— a mentális egészség védelméről szóló törvény. ${ }^{34}$

Az alkotmány rendelkezik arról, hogy mindenkinek joga van az egészsége megőrzéséhez, és ehhez a közhatalmi szervek által fenntartott intézményrendszer társul. ${ }^{35}$ Járványhelyzet esetén, amilyen például a koronavírus-járvány is, a veszélyhelyzetre vonatkozó jogi normákat kell alkalmazni, azaz a következő alapjogok korlátozhatók egészségügyi veszélyhelyzet idején: a gazdasági tevékenység szabadsága, a személyes szabadság, a magánlakás sérthetetlensége, a mozgás- és letelepedési szabadság, a sztrájkjog, a tulajdonhoz való jog, a munkához való jog, a biztonságos és egészséges munkakörülményekhez való jog, a pihenéshez való jog.

Konkrétan a járványügyi helyzetben alkalmazott korlátozásokrób ${ }^{36}$ a 2020. április 1 . és 2020. június 30. között hatályos jogszabály rendelkezik. Ebben részletesen felsorolják a lehetséges korlátozó intézkedéseket:

— az üzleti tevékenység meghatározott területeinek ideiglenes korlátozása;

- a készlet átmeneti meghatározása egy bizonyos típusú termékcsoport esetén;

- betegek és betegséggyanús személyek orvosi vizsgálata, valamint egyéb megelőző intézkedések és kezelések alkalmazásának kötelezettsége;

- a karantén elrendeléséről szóló rendelkezés aláirására vonatkozó kötelezettség;

- karanténlétesítmény kijelölése;

- a helyiségek vagy területek használatának ideiglenes korlátozása és azok biztosításának kötelezettsége;

- meghatározott időponttól történő evakuálási utasítás meghatározott helyekről, területekról és létesítményekből;

— a meghatározott helyeken és létesítményekben, valamint bizonyos területeken való tartózkodás elrendelésének tilalma;

— beteg és betegséggyanús személyek számára a „nulla” zónából való kilépés tilalma;

— a szabad mozgás korlátozása. ${ }^{37}$

31 A betegek jogairól és a betegek ombudsmanjáról szóló, 2008. november 6-i törvény (Ustawa z dnia 6 listopada 2008 r.o prawach pacjenta i Rzeczniku Praw Pacjenta).

32 2004. augusztus 27-i törvény a közpénzekből finanszírozott egészségügyi szolgáltatásokról (Ustawa z dnia 27 sierpnia 2004 r. o świadczeniach opieki zdrowotnej finansowanych ze środków publicznych).

$33 \mathrm{Az}$ orvosi tevékenységről szóló 2011. április 15-i törvény (Ustawa z dnia 15 kwietnia 2011 r. o działalności leczniczej).

34 A mentális egészség védelméről szóló 1994. augusztus 19-i törvény (Ustawa z dnia 19 sierpnia 1994 r. o ochronie zdrowia psychicznego).

35 Alkotmány 68. cikk.

36 Az emberi fertőzések és fertőző betegségek megelőzéséról és leküzdéséről szóló 2008. december 5-i törvény (Zasady postępowania w razie stanu zagrożenia epidemicznego i stanu epidemii) (a továbbiakban: Járványügyi tv.).

37 Járványügyi tv. 46b. cikk. 
Fontos rendelkezés még, hogy a közszolgáltatási szerződések nem vonatkoznak a járvány megelőzésével vagy felszámolásával kapcsolatban odaítélt szolgáltatási, árubeszerzési vagy építési beruházási szerződésekre olyan területen, ahol járványügyi vészhelyzetet vagy járványállapotot állapítanak meg. ${ }^{38}$

\subsection{A koronavírus-járvány első hulláma Lengyelországban}

A Lengyel Köztársaságban nem rendeltek el veszélyhelyzetet. ${ }^{39}$ Azonban - még az első lengyelországi fertőzött regisztrálása előtt kezdeményezve - március 8-i hatállyal elfogadták a Covid-19 és más fertőző betegségek, valamint az általuk okozott vészhelyzetek megelőzésével és leküzdésével kapcsolatos speciális megoldásokról szóló törvényt (a továbbiakban: Covid-19 tv.). A számos módosítást megélt törvény a koronavírus-járvány során alkalmazandó alapelvek, eljárások, illetve a közigazgatási szervek feladatainak meghatározásán túl ${ }^{40}$ - egyéb más jogszabály mellett - jelentősen módosította az emberi fertôzések megelőzéséről és leküzdéséről szóló törvényt (a továbbiakban: Járványügyi tv.), különös tekintettel annak járványveszélyről (stanu zagrożenia epidemicznego) és járványhelyzetről (stanu epidemii) szóló rendelkezéseire. ${ }^{41} \mathrm{~A}$ Járványügyi tv. korábban is lehetőséget adott arra, hogy - a járvány által érintett vajdaságok számának függvényében - a vajda vagy az egészségügyért felelős miniszter a tartományi, illetve állami szintû egészségügyi felügyelőséggel (Inspektorat Sanytarny) konzultálva rendeletével járványveszélyt vagy járványhelyzetet hirdessen ki, és annak megfelelő intézkedéseket alkalmazzon. ${ }^{42}$ A törvénymódosítás - olyan mértékú járvány esetén, amely meghaladja az illetékes kormányzati, illetve önkormányzati szervek lehetôségeit - rendeletalkotási joggal ruházza fel a Minisztertanácsot, amely ez alapján a veszélyeztetettségnek megfelelően zónákat hozhat létre, és a Járványügyi tv. adta keretek között korlátozó intézkedéseket hozhat. ${ }^{43}$ Mindezek alapján az egészségügyért felelős miniszter rendeletével március 13 -án járványveszélyt, ${ }^{44}$ majd pedig március 20-tól járványhelyzetet hirdetett ki a Lengyel Köztársaság egész területére. ${ }^{45}$

Magyarországhoz hasonlóan Lengyelországban is intenzív jogalkotási munkát követelt az első hullám, amelynek eredménye négy úgynevezett Covid-törvény:

38 Járványügyi tv. 46b. cikk.

39 Hojnyák-Ungvári, 2021.

40 Covid-19 tv. 1. cikk.

41 Covid-19 tv. 25. cikk.

42 Járványügyi tv. 46. cikk (1)-(2) bekezdés.

43 Járványügyi tv. 46a. cikk.

44 Az egészségügyi miniszter 2020. március 13-i rendelete a járványveszély Lengyel Köztársaság területén való bevezetéséről.

45 Az egészségügyi miniszter 2020. március 20-i rendelete a járványhelyzet Lengyel Köztársaság területén való bevezetéséről. 
— a Covid-19-rôl szóló első törvény, amely 2020. március 31-én és április 1-jén lépett hatályba; ${ }^{46}$

— a Covid-19-rôl szóló második törvény, amely 2020. április 18 -án lépett hatályba; ${ }^{47}$

- a Covid-19-rôl szóló harmadik törvény, amely a Covid-19 elterjedése megakadályozásának érdekében hozott különböző törvények megváltoztatásáról szól, és 2020. május 16-án lépett hatályba; ${ }^{48}$

- a Covid-19 negyedik törvénye 2020. június 19-én kelt, a vállalkozásoknak nyújtott banki kölcsönök kamatlábainak állami támogatásáról szól, és 2020. június 24-én lépett hatályba. ${ }^{49}$

Fontos hangsúlyozni, hogy a koronavírus-járvány a jogalkotást is új kihívások elé állította, és szorosabb együttmúködést követel meg a központi kormányzatok és parlamentek között. Ez a helyzet Lengyelországra is igaz, mivel a járvány kitörése óta a képviselőház és a szenátus szorosabb együttmúködésben tevékenykedik..50

A járvány hatékony megelőzése érdekében többek között az alábbi egészségbiztonsági intézkedéseket írták elő:

2020. március 15-én lezárták az ország határait;

- kötelező karantént rendeltek el a külföldiek és a hazájukba visszatérő lengyelek számára;

- a közoktatási és felsőoktatási intézményeket bezárták;

- az élelmiszerboltok, gyógyszertárak, benzinkutak kivételével bezárták a bevásárlóközpontokat;

— betiltották a nyilvános összejöveteleket;

- 2 méteres kötelező távolságtartást vezettek be;

- lezárták a játszótereket, parkokat;

— korlátozták a tömegközlekedési eszközökön utazók számát;

— bezárták az éttermeket, és csak elviteles kiszolgálást engedélyeztek;

46 A Covid-19, az egyéb általa okozott fertőző betegségek és vészhelyzetek megelőzésével és leküzdésével kapcsolatos különleges megoldásokról szóló törvény (Ustawa z dnia 31 marca 2020 r. o zmianie ustawy o szczególnych rozwiązaniach związanych z zapobieganiem, przeciwdziałaniem i zwalczaniem COVID-19, innych chorób zakaźnych oraz wywołanych nimi sytuacji kryzysowych oraz niektórych innych ustaw).

47 2020. április 16-i törvény a SARS-CoV-2 vírus terjedésével összefüggésben meghatározott támogató eszközökről (Ustawa z dnia 16 kwietnia 2020 r. o szczególnych instrumentach wsparcia w związku z rozprzestrzenianiem się wirusa SARS-CoV-2).

48 2020. május 14-i törvény a SARS-CoV-2 vírus terjedésével összefüggésben hozott egyes jogszabályok módosításáról (Ustawa z dnia 14 maja 2020 r. o zmianie niektórych ustaw w zakresie działań osłonowych w związku $\mathrm{z}$ rozprzestrzenianiem się wirusa SARS-CoV-2).

49 2020. június 19-i törvény a Covid-19 hatásai által érintett vállalkozóknak nyújtott banki kölcsönök kamattámogatásáról (Ustawa z dnia 19 czerwca 2020 r. o dopłatach do oprocentowania kredytów bankowych udzielanych przedsiębiorcom dotkniętym skutkami COVID-19 oraz o uproszczonym postępowaniu o zatwierdzenie układu w związku z wystąpieniem COVID-19).

50 Krzysztof-Rudnicki, 2020, 105. o. 
— a fitneszklubok, éjszakai klubok, mozik, fürdők, színházak, uszodák is bezárásra kerültek;

— korlátozták az egyes üzletekben tartózkodók létszámát;

- bevezették az idősek vásárlási idősávját;

— a vallási istentiszteleteken részt vevők számát is korlátozták.

\subsection{A koronavírus-járvány második hulláma Lengyelországban}

A kézirat lezártakor is hatályban lévő intézkedések sokkal részletesebbek és kiterjedtebbek, mint az első hullám idején, és gyakorlatilag az élet minden területére kihatnak. A lengyel szabályozás előírja, hogy gyalogosok között kötelező legalább 1,5 méteres távolságot tartani, ami alól mentesülnek a 13 évnél fiatalabb gyermeket gondozó szülők, az ugyanazon háztartásban élők, valamint a fogyatékossággal élő, önállóan mozogni képtelen személyek, sajátos nevelési igényủ személyek és gondozóik.

A járvány lassítása szempontjából Lengyelországban is részletesen szabályozták a maszkviselést, miszerint kötelező maszkot viselni az utcákon, utakon és a városi tereken, temetőkben, sétányokon, közutakon, parkolókban, buszokon, villamosokon és vonatokon, üzletekben, bevásárlóközpontokban, bankokban, piacokon és postahivatalokban, mozikban és színházakban, orvosi rendelőkben, járóbeteg-rendelőkben és kórházakban, masszázsés tetoválószalonokban, templomokban, iskolákban és egyetemeken, és a kormányhivatalokban is. Az erdőkben, parkokban, zöld tereken, botanikus kertekben, történelmi kertekben, családi közösségi kertekben és a strandokon, valamint személygépkocsival történő utazás közben azonban a maszk viselése nem kötelező. ${ }^{51}$

A kézirat lezártakor hatályos szabályok ${ }^{52}$ jelentősen korlátozták egyes korcsoportok személyes mozgását is. İgy például hétfőtől péntekig, reggel 8 és 16 óra között a 16 éven aluli gyermekeket szülő vagy gondozó felügyelete alatt kell tartani, miközben egyik helyról a másikra mennek. A szabály nem vonatkozik az iskolába utazó vagy az iskolából hazatérő gyermekekre és a hétvégékre sem.

51 A koronavírus-helyzetre vonatkozó szabályokat tartalmazó tematikus oldal: www.gov.pl/web/coronavirus/ temporary-limitations (Letöltve: 2020. december 15.)

52 2020. december 9-i törvény a Covid-19, más fertőző betegségek és az általuk okozott krízishelyzetek megelőzésével és leküzdésével kapcsolatos speciális megoldásokról szóló törvény és néhány más törvény módosításáról (Ustawa z dnia 9 grudnia 2020 r. o zmianie ustawy o szczególnych rozwiązaniach związanych z zapobieganiem, przeciwdziałaniem i zwalczaniem COVID-19, innych chorób zakaźnych oraz wywołanych nimi sytuacji kryzysowych oraz niektórych innych ustaw Dz.U.2020.2255). 
2020. november 28-tól ${ }^{53}$ új szabályok vonatkoznak a karanténra (egészséges egyén bezárása fertőzésnek való kitettség miatt) és az izolációra (egy személy izolálása az első Covid-19 diagnosztikai teszt pozitív eredménye miatt). Az otthoni elszigetelés 10 napig tart, feltéve, hogy a beteg nem mutat Covid-19-tüneteket. Ha a koronavírus tünetei az izoláció során jelentkeznek, akkor az elsődleges egészségügyi orvos meghosszabbítja az elszigetelés időtartamát, amely nem érhet véget korábban, mint a tünetek megjelenésétől számított 13 napon belül. A kórházakban és elszigetelő osztályokon történő elszigetelés esetén annak időtartama végét a betegért felelös orvos határozza meg, de nem következhet be korábban, mint a tünetek megjelenésétől számított 13 napon belül, ahol az utolsó három napnak tünetmentesen kell eltelnie.

A karantén 10 napig tart, ha a Covid-19 tünetei nem jelentkeztek. A tünetmentes személyek karanténban történő tesztelésével felhagytak. A karantén ideje alatt a karanténban lévő nem hagyhatja el otthonát, nem sétálhat a kutyájával, nem vásárolhat, orvoshoz nem látogathat; ha a karanténban lévő személy szoros kapcsolatban áll más személyekkel otthon, akkor ôket is karanténba kell helyezni, amennyiben pedig a betegség tüneteit tapasztalja (rossz közérzet, láz, köhögés, légszomj), ezt telefonon be kell jelentenie az egészségügyi és járványügyi állomásra..$^{54}$

A kulturális intézmények, köztük a színházak, mozik, múzeumok, múvészeti galériák és kulturális központok tevékenysége fel van függesztve. November 28-tól könyvtárak nyithatnak, feltéve, hogy a létesítményben tartózkodó minden személy számára $15 \mathrm{~m}^{2}$ terület áll rendelkezésre a gyưjtemények rendelkezésre bocsátására. Ez a rendelkezés 2020. december 27-ig hatályos. ${ }^{55}$

A templomokban az emberek száma korlátozott: $15 \mathrm{~m}^{2}$-enként legfeljebb 1 fó, legalább 1,5 m távolságot tartva másoktól. Ha egy adott esemény egy épületen kívül zajlik, a résztvevőknek 1,5 m távolságot kell tartaniuk, és el kell takarniuk a szájukat és az orrukat.

Az egyéb szabadtéri rendezvények esetén $1,5 \mathrm{~m}$ távolságot kell tartani másoktól, és el kell takarni a szájat és az orrot. A nyilvános összejöveteleken legfeljebb 5 fó vehet részt. A résztvevők kötelesek eltakarni a szájukat és az orrukat és 1,5 méter távolságot tartani egymástól. Ezenkívül az összejöveteleket nem lehet 100 m-nél kisebb távolságra szervezni. Az esküvőket és egyéb ünnepléseket betiltották. Az éjszakai klubok és egyéb helyek is bezá-

53 A Covid-19, az általuk okozott egyéb fertőző betegségek és vészhelyzetek megelőzésével és leküzdésével kapcsolatos speciális megoldásokról szóló törvény módosításáról szóló, 2020. november 27-i törvény (Ustawa z dnia 27 listopada 2020 r. o zmianie ustawy o szczególnych rozwiązaniach związanych z zapobieganiem, przeciwdziałaniem i zwalczaniem COVID-19, innych chorób zakaźnych oraz wywołanych nimi sytuacji kryzysowych oraz niektórych innych ustaw).

54 A Minisztertanács 2020. november 26-i rendelete a járvány kapcsán egyes korlátozások, parancsok és tilalmak megállapításáról (Rozporządzenie Rady Ministrów z dnia 26 listopada 2020 r. w sprawie ustanowienia określonych ograniczeń, nakazów i zakazów w związku z wystąpieniem stanu epidemii) (a továbbiakban: Járvány r.) 2. fejezet.

55 Járvány r. 10. $\$$ (1) bekezdés. 
rásra kerültek. Vásárokat, kiállításokat, kongresszusokat és konferenciákat csak online lehet megrendezni..$^{56}$

2020. június 13-án Lengyelország újraindította a határforgalmat az EU belső határain belül. Ez azt jelenti, hogy az EU belső határainak utazása és átlépése megengedett. Az utazók visszanyerték jogukat a Lengyel Köztársaság területére való szabad belépéshez, elhagyáshoz vagy átszállításhoz. Karantén nem szükséges. Figyelembe kell venni a szomszédos országban érvényben lévő korlátozásokat, miközben külföldi utazást tervezünk. A korlátozások azokra a külföldiekre vonatkoznak, akik átlépik az EU külső határát.

Az éttermekben tilos üzleti tevékenységet folytatni, és csak elvitelre lehet ételt készíteni. $\mathrm{Ez}$ a tilalom az iskolai étkezdék üzemeltetésére is vonatkozik. Az ételeket csak az általános iskola 1-3. osztálya és az oktatási személyzet számára lehet megfeleló egészségügyi óvintézkedések bevezetése után felszolgálni. Étterem üzemeltetése a szállodákban engedélyezett, de csak a szálloda vendégeinek, akik legalább egy éjszakát ott töltenek. Megengedett a szálloda éttermeinek múködtetése, de az ételeket a szálloda vendégeinek a szobájukba kell szállítani..$^{57}$

Országszerte szépségszalonok, tetoválószalonok, fodrászok és kozmetikusok múködhetnek megfelelő óvintézkedések mellett. A munkaállomásoknak legalább 1,5 m-re kell lenniük egymástól, kivéve, ha a padló felületétől legalább 2 m magas válaszfalak választják el ôket.

A szállodák korlátozottan múködnek, és csak üzleti úton lévő vendégek, edzôtáborokban és sportversenyeken részt vevő sportolók, egészségügyi szakemberek, betegek és gondozóik szállásfoglalása engedélyezett. A munkavállalók szállói is múködhetnek. ${ }^{58}$

Az uszodák, aquaparkok, edzőtermek, fitneszklubok és -központok múködése országszerte szünetel, kivéve azokat, amelyek terápiás tevékenységeket végeznek, sportversenyek, sporttevékenységek vagy -események részeként sportolók számára készültek, diákok és tanulók számára készültek az egyetemi vagy iskolai órák részeként. ${ }^{59}$

Országszerte sportversenyeket, -foglalkozásokat és -rendezvényeket szerveznek a nyilvánosság részvétele nélkül. A sportórákon, -eseményeken és -versenyeken (kivéve a golfpályákat, teniszpályákat, istállókat, ménesbirtokokat és lóversenypályákat, a vízi és a légi sport infrastruktúráját, amely nem korlátozódik a maximálisan engedélyezett létszámra) legfeljebb 250 résztvevő lehet egyszerre, az eseményt szervező embereket nem számítva. ${ }^{60}$ 


\section{A különleges jogrend és a járványhelyzet kihirdetésével kapcsolatos tapasztalatok, jogviták}

Komoly közjogi viták alapját képezte, ${ }^{61}$ hogy a veszélyhelyzet kihirdetése helyett - a Covid-19 tv. elfogadásával és a járványhelyzet kihirdetésével - egy negyedik, kvázi rendkívüli intézkedést fogadtak el az alkotmány megkerülésével. Ugyanis előbbi elrendelése egyes vélemények szerint megalapozott lett volna, a járványhelyzet pedig - azáltal, hogy különös veszély miatt rendelték el, annak keretében alapvető jogokat és szabadságokat korlátoznak, és az államapparátus rendes müködését is megváltoztatják - magán hordozza a különleges jogrendi szituációk jellemzőit. ${ }^{62}$

Az előbbieken felül Lengyelországban heves közjogi vita folyt az elnökválasztás időzítéséről. A vírus felgyorsulása és a kormány által a további terjedés elkerülése érdekében bevezetett egyre korlátozóbb intézkedések heves vitát váltottak ki azzal kapcsolatban, hogy az elnökválasztás egyáltalán folytatódhat-e. Az összes ellenzéki jelölt a választás elhalasztása mellett állt ki, azzal érvelve, hogy az ország tényleges szükségállapotban van, ami gyakorlatilag lehetetlenné teszi a normális választási kampányt. Azzal vádolták a Jog és Igazságosság Pártját, hogy a lengyelek egészségét politikai haszonszerzés céljából feláldozzák azzal, hogy választásokat folytatnak, amikor ez veszélyes. Érvelésük szerint a legfontosabb, hogy a hatóságok mindent megtegyenek a vírus elleni küzdelemben és megvédjék a gazdaságot. Március végén az ellenzéki jelölt, Małgorzata Kidawa-Błońska teljesen felfüggesztette kampányát, és a választások bojkottjára szólított fel.

A Jog és Igazságosság Pártja azonban nem volt hajlandó engedni az ellenzéki követeléseknek, és ragaszkodott ahhoz, hogy a választásokat a tervezett ütemtervnek megfelelően tartsák meg, azzal érvelve, hogy az elhalasztás korai lenne, és válság idején destabilizálná a politikai rendszert. Azt állították, hogy az ellenzék önérdekből követelte a választás elhalasztását, és céljuk volt egy olyan választás legitimitásának megkérdőjelezése, amelyet nagy valószínúség szerint el fognak veszíteni.

Mindazonáltal - annak ellenére, hogy léteznek feltételek a választási kampány lebonyolításához - néhány szakértő azzal érvelt, hogy egy epidemiológiai vészhelyzetben egyszerúen múszakilag lehetetlen választásokat lebonyolítani. Figyelmeztettek, hogy ilyen körülmények között történő próbálkozás aláássa a választások hitelességét, ami - tekintettel arra, hogy a demokrácia az állami intézményekbe és a választási eljárásokba vetett bizalomra épül - súlyos következményekkel járhat a lengyel politikai rendszer és a nemzeti stabilitás szempontjából, különösen egy ilyen politikailag megosztott és polarizált helyzetben lévő országban. A választások megszervezése óriási logisztikai kihívás, amely Lengyelországban körülbelül egymillió (gyakran idős) embert érint, akiket (általában nagy csoportokban) ki 
kell képezni, ráadásul sok lengyel jelenleg külföldön, „bezárt” országokban él, és elutasítja a szavazást, míg az idősebb és sérülékenyebb szavazókat valószínúleg még májusban karanténba helyezték, sokan mások önként vonultak karanténba, vagy egyszerüen nem akarták kockáztatni a részvételt. ${ }^{63}$

A lengyel alkotmány - garanciális szabályként - rendkívüli jogrend idején és annak megszúnését követő kilencven napon belül nem teszi lehetővé országos népszavazás és választások megtartását, így például a köztársasági elnök megbízási ideje ilyenkor meghoszszabbodik. ${ }^{64}$ Azáltal azonban, hogy a Minisztertanács nem hirdetett ki veszélyhelyzetet, az elnökválasztásnak nem volt alkotmányos akadálya, ${ }^{65}$ emiatt pedig sokan sejtettek politikai okot a különleges jogrend bevezetésének elmaradása mögött. ${ }^{66}$

Lengyelországban 2020. május 21-én a maszkviselés szabályaival kapcsolatban is alakult ki jogi vita a kormány és az ombudsman ${ }^{67}$ között. Az ombudsman állásfoglalásában kifejtette, hogy a kötelező maszkviselésnek elsősorban az állampolgárok magatartásából kell létrejönnie, nem egy rendelet miatt. Az alkotmány ${ }^{68}$ alapján a rendeleteket az alkotmányban meghatározott szervek adják ki, alapszabály részletes felhatalmazása alapján és annak végrehajtása céljából. Ez azt jelenti, hogy a maszkviselés szabályait törvényi szinten kellett volna rögzíteni, mivel így garantálható annak társadalmi elfogadottsága, támogatottsága.

A járványügyi intézkedésekkel kapcsolatban az ombudsman rámutatott arra is, hogy törvényi alap nélkül a hatóságok korlátozták az állampolgárok három fontos szabadságát: az emberi és állampolgári jogok szabadságát, ${ }^{69}$ a Lengyel Köztársaság területén belüli szabad mozgást, ${ }^{70}$ valamint a lelkiismeret és a vallás szabadságát. ${ }^{71} \mathrm{Az}$ alkotmány itt egyértelmúvé teszi: ezek túl fontos jogok ahhoz, hogy egy miniszter döntsön róluk, azaz ezek nem korlátozhatók rendeleti szinten. ${ }^{72}$

63 Szczerbiak, 2020.

64 Alkotmány 228. cikk (7) bekezdés.

65 Végül a lengyel elnökválasztás első fordulóját 2020. június 28-án, a másodikat pedig július 13-án tartották meg.

66 Drinóczi-Bien-Kacala, 2020, 190. o.

67 Ombudsmani állásfoglalás a maszkviselésről. Elérhető: www.rpo.gov.pl/pl/content/koronawirus-rponakaz-zakrywania-ust-nosa-niezgodny-z-zasadami-tworzenia-prawa (Letöltve: 2020. december 15.).

68 Alkotmány 1 . cikk.

69 Alkotmány 30. cikk.

70 Alkotmány 52 . cikk.

71 Alkotmány 53. cikk.

72 Ombudsmani állásfoglalás az egészségügyi miniszter rendeleteiről. Elérhető: www.rpo.gov.pl/pl/content/ koronawirus-rpo-rozporzadzenia-MZ-niezgodne-z-ustawa (Letöltve: 2020. december 15.). 


\section{5. Összegzés}

A magyar Alaptörvényben szabályozottakhoz képest a lengyel szabályozásban a különleges jogrendi esetkörök lényegesen egyszerübben szabályozottak. A lengyel környezetben a szabályozási esetkörök szưkebbre szabottsága mellett a jogosítotti kör sem heterogén, ennek következtében a felelősség is egy magasabb - jelen esetben a lengyel minisztertanácsi/ államfői - szinten manifesztálódik.

A lengyel alkotmány megfeleló mintát szolgáltat a fogalmi letisztázáshoz, az operativitás növeléséhez amellett, hogy rövid időn belül lehetôséget teremt a törvényhozás számára, hogy annulálja az elrendelést, és ha szükséges, megkezdje a felelősségre vonást. ${ }^{73}$

Az alkotmány részletesen felsorolja, hogy mely alapjogok nem korlátozhatók, és melyek azok, amelyek ha a körülmények úgy alakulnak, akkor korlátozás alá eshetnek. Ezen belül is elkülönítik a hadiállapot és szükségállapot alatt korlátozható alapjogokat a veszélyhelyzet idején korlátozható alapjogoktól.

Fontos megemlíteni, hogy a jelenlegi, koronavírus okozta helyzetben szigorú korlátozó intézkedések kerültek bevezetésre. A lengyel rendszer a magyarnál kevésbé túlszabályozott, ami a különleges jogrendi esetköröket illeti. Több más aspektusában is egyszerúbb a lengyel szabályozás, így egyik szituáció során sem kerül sor új szerv megalkotására, és mindhárom esetben a Minisztertanács jogosult rendeleti kormányzásra. Mindezek pedig segítik az átállás nehézségeinek leküzdését, valamint az operativitást. A lengyel szabályozás továbbá lehetőséget teremt arra, hogy a törvényhozás rövid időn belül annulálja a különleges jogrend elrendelését, hiszen a hadiállapot és a szükségállapot bevezetésétől számított 48 órán belül a köztársasági elnöknek kezdeményeznie kell a rendelet képviselőházi ellenjegyzését. A képviselőház pedig annak haladéktalan megtárgyalását követően a képviselők legalább felének jelenlétében, abszolút többséggel hatályon kívül helyezheti a különleges jogrendet kihirdető rendeletet. Veszélyhelyzet esetén pedig annak az egész ország területére való kiterjesztéséhez szükséges a képviselőház jóváhagyása.

Az alábbi táblázat összefoglalja azt, hogy a lengyel alkotmányos és törvényi szintú szabályok egészen pontosan milyen rendkívüli jogrendi helyzeteket szabályoznak, és azokat mikor és mely szerv rendelheti el.

73 Kelemen, 2019, 9. o. 


\begin{tabular}{|c|c|c|c|}
\hline & Hadiállapot & Szülkségállapot & Veszélyhelyzet \\
\hline $\begin{array}{c}\text { Szabályozás } \\
\text { szintje }\end{array}$ & \multicolumn{3}{|c|}{ alkotmányos és törvényi szint } \\
\hline Elrendelési okok & $\begin{array}{l}\text { — az állam külső } \\
\text { fenyegetettsége } \\
\text { — a Lengyel Köztársaság } \\
\text { területe elleni fegyveres } \\
\text { agresszió } \\
\text { — nemzetközi egyezmény } \\
\text { szerinti közös védelmi } \\
\text { kötelezettség }\end{array}$ & $\begin{array}{l}\text { — az alkotmányos rend } \\
\text { fenyegetettsége } \\
\text { — az állampolgárok } \\
\text { fenyegetettsége } \\
\text { — a közrend } \\
\text { fenyegetettsége }\end{array}$ & $\begin{array}{l}\text { - természeti } \\
\text { katasztrófa } \\
\text { — műszaki baleset }\end{array}$ \\
\hline Elrendelés & \multicolumn{2}{|c|}{$\begin{array}{l}\text { A Minisztertanács kérelmére a köztársasági elnök } \\
\text { hirdeti ki, azonban a bevezetésétől számított } 48 \text { órán } \\
\text { belül kezdeményezi a rendelet képviselőházi ellen- } \\
\text { jegyzését. A képviselőház pedig a képviselők legalább } \\
\text { felének jelenlétében, abszolút többséggel hatályon } \\
\text { kívül helyezheti a köztársasági elnök rendeletét. }\end{array}$} & $\begin{array}{l}\text { A Minisztertanács } \\
\text { hirdeti ki, kiterjeszté- } \\
\text { séhez viszont a képvi- } \\
\text { selőház jóváhagyása } \\
\text { szükséges. }\end{array}$ \\
\hline Felhatalmazott & \multicolumn{3}{|c|}{ Minisztertanács } \\
\hline Gyakorlati esetek & \multicolumn{2}{|c|}{ Nem került sor az elrendelésükre. } & $\begin{array}{l}\text { Elrendelésére nem } \\
\text { került sor, azonban } \\
\text { több alkalommal } \\
\text { komolyan felmerült } \\
\text { a lehetősége (például } \\
\text { a 2010-es és a 2013-as } \\
\text { árvizek idején). }\end{array}$ \\
\hline $\begin{array}{l}\text { Rendkívüli felha- } \\
\text { talmazás esetkörei }\end{array}$ & \multicolumn{3}{|c|}{$\begin{array}{l}\text { — terrorizmus (a különleges jogrendi törvények alapján) } \\
\text { — válsághelyzet (a válságkezelésről szóló törvény alapján) }\end{array}$} \\
\hline
\end{tabular}

\section{3. táblázat}

A különleges jogrendi esetkörök Lengyelországban

Forrás: a szerző saját összeállítása 


\section{Irodalomjegyzék}

BAŁA, P. (2020) 'Constitutional Failure. Regulacja stanów nadzwyczajnych i zbliżonych w Konstytucji RP z 2 kwietnia 1997 r. a praktyka ustrojowa zwalczania epidemii COVID-19/ SARS-CoV-2', Przegląd Konstytucyjny, 2020/2, 68-121. o.

Drinóczi, T., Bien-KacAla, A. (2020) 'COVID-19 in Hungary and Poland: Extraordinary Situation and Illiberal Constitutionalism', The Theory and Practice of Legislation, 8(1-2), 171-192. 0 .

HoJNYÁK, D., UngVÁRI, Á. (2021) 'A Visegrádi Együttműködés országainak koronavírusjárványra adott válasza', Iustum Aequum Salutare, (17)1, 305-323. o.

KELEMEN, R. (2019) 'A különleges jogrend szabályozása az egyes alkotmányokban II. A lengyel, cseh és szlovák különleges jogrend alkotmányos szabályai', Vélemények a katonai jog világából, 2019/2. [Online]. Elérhető: https://epa.oszk.hu/02700/02733/00010/pdf/ EPA02733_velemenyek_katonai_2019_02.pdf (Letöltve: 2020. december 10.)

KrzyszTOF, K., RUDNICKI, J. (2020) 'The COVID Crisis as a Sample Tube with Contemporary Legal Phenomena', Central European Journal of Comparative Law, 1(2), 105-121. o.

LAKATOS, L. (2014) 'A különleges jogrend és a honvédelem szabályzása' MTA Law Working Papers, 2014/49 [Online]. Elérhető: https://jog.tk.hu/mtalwp/a-kulonleges-jogrend-es-ahonvedelem-szabalyzasa (Letöltve: 2020 . december 8.)

Szczerbiak, A. (2020) How Is the Coronavirus Pandemic Affecting Polish Politics? [Online]. Elérhető: https://polishpoliticsblog.wordpress.com/2020/04/02/how-is-the-coronaviruspandemic-affecting-polish-politics/ (Letöltve: 2020. december 15.) 